\title{
Myths and Narratives for Management
}

\author{
Ulrich Gehmann ${ }^{1}$ \\ ${ }^{1}$ Department of History, Karlsruhe University (KIT), Karlsruhe, Germany \\ Correspondence: Ulrich Gehmann, Faculty of the Humanities, Department of History, Karlsruhe University (KIT), \\ Karlsruhe 76133, Karlstr. 40, Germany. Tel: 0049-177-442-3099. E-mail: ugehm@ t-online.de
}

Received: October 21, 2015

Accepted: November 11, 2015

Online Published: December 25, 2015

doi: 10.5539/ibr.v9n1p123

URL: http://dx.doi.org/10.5539/ibr.v9n1p123

\begin{abstract}
Having in mind the social, human, cultural and systemic problems management is confronted with today, but also the intricate relationships between art and technique, the recent predominant understanding of what 'management' is settles upon its technical, that is, essentially functional character. The thesis is that this basic character has not changed, despite all attempts to redefine, modify, or even re-think management as a cultural practice. Related to this basic character, some elements of the mind set underlying such an understanding of 'management' shall be examined, elements which may be called mythic.

For such a mind set, management is primarily conceived as a function, and as in case of every process that is technical in its essence, it finally aims at an objectification and optimization of the entities it has to deal with. That functional character, and out of it, the desire for dominating the respective entities by formatting them rests on certain assumptions about a 'relevant' world, assumptions to be examined in this contribution.
\end{abstract}

Keywords: management understanding, mythology, functionalism, history of ideas

\section{Introduction}

\subsection{The Problem}

Irrespective of its practical applications, management is a mythological issue. And despite all criticisms and claims to re-think and re-consider it, re-thinking management proves to be a difficult issue. Not because of various academic approaches to that matter (e.g. Bachmann-Medick, 2009), but because of the prevailing management praxis the author could experience; who worked in management for many years. This is quite an important point to be kept in mind, since reflecting upon something, and in particular upon something that has the relevance it has for modern and post-modern sociocultural contexts-as management has-is very different from practicing it; from its performance on a daily base in its actual terms and facticity.

\subsection{The Importance of the Problem}

Although it might look so at first glance, this is not a trivial statement. Because as far as the author experienced it, these actual terms both rest upon and generate a certain pre-understanding, a kind of an Unthought Known (Bollas, 1987) that not only legitimates but reasserts our actions. It is about basic assumptions which are of an implicit nature and which, opposed to academic, "critical" reflection, are not doubted in an organizations' actual conduct. And they have not to be doubted, to keep that organization running. Inside the terms of such a daily actual conduct, one may reflect upon them, even criticize them-but never truly doubt them. Since they are of a mythic nature, which is their most decisive aspect to come to. In a self-referential loop, they provide the base (and hence, justification) of the activities undertaken, as well as those activities validate the "rightness" of these assumptions. And by having a mythic nature, they are culturally grounded; not just in the 'culture' of the organization in question, but also in the wider cultural context that organization is embedded in. So, when talking about a re-thinking of management-which is actual conduct, at the end of the day (managers would say)-we have to address this mythic nature mentioned, the dynamics it does generate.

What shall be pursued is a twofold approach: On the one hand, a history of ideas has to be looked at, illuminating that wider context and its mythic elements. And on the other, both of them have to be examined from the background of the experiences the author could gain in his actual conduct. Since the personal background contributes to the kind of thinking one undertakes, too about re-thinking. It was the one of achieving a real cultural turn and to establish a real re-thinking of management, in both the latter's mythological and 
practical dimensions. The author worked abroad as a manager in charge for an international consultancy firm, and the decisive aim of the mission was to achieve a "transition process"; large scaled, for entire countries. Cultures with their aligned management-understanding had to be transformed, converting them into what may be called a mythology of the free market. That liberated individuals count (no matter if firms or persons), not the collective. That a mythology had to cease, and another one to take its place; which was a turn in culture, its aligned disruptions included.

\section{On Myths and Moral}

What is an 'unthought' known? In terms of comprehension, the Unthought Known is equivalent to a tacit knowledge (equivalent to, but not entirely not identical with) that not only underlies our daily activities, e.g. in management, but also justifies them and grounds them morally; which can considered to be even more important. Inside the framework of a practiced everyday systemic of management, it does lead to a phenomenon known in the system theories as operational closure. Technically speaking, it is the overall situation that a system-e.g., a 'system' of managers and their management values, as well as the associated 'other' system, the one that has to get managed (an enterprise, or any other institutionalized organization)-is reproducing itself by referring to itself, and that on a constant base. Or formulated as practical outcome: The organization in question uses its own operations as argument for its own operations (Baecker, 1999, p. 161).

This too is neither trivial, nor self-evident. But it generates, as an ongoing process and based on the authors' evidence, its own kind of self-evidence. Which accounts for that organizations' very self-understanding then (who are we, who the others, what is the "nature" of our business), altogether with a peculiar morality assigned to it: Not only why it is justified what we are doing here, but moreover, why it is right what we are doing here; which is not identical albeit very closely related to each other. The latter dimension can be abbreviated as the "moral" or mythological dimension of management and finally defines, being a constitutive part of that Unthought Known addressed above, the actual cultural terms and out of this, the terms of understanding specific for the organization in question: how we interpret phenomena, in particular events? What they mean for us? Not just confined to the actual situation, but in general, for us as an organization as a whole? Related, it is about our very self-understanding as an organization: what is our raison d' etre, our reason to exist-as this kind of organization, and no other? Whereby the 'kind' is not a one of a rationalized functionality (we, as an organization, are in this and this industry, have these strategic goals, etc.), but an attribution in terms of culture-it refers to the pre-understanding (the respective Unthought Known) who we are and where we are, inside the context of a world conceived as being "relevant" for us.

\subsection{Myths as Relevant Narratives}

When we look more closely at such a mythological dimension, what it is? How is it constituted, consisting of which elements? Moreover, what is a mythos, in these regards? A mythology, to be comprehended functionally as a system of myths, consists of a set of central beliefs (that very 'system') which can be understood as core beliefs about the nature of the "world as it is", to use that mythological term; how it came into being; and what the position and meaning of man is, inside the frame of this context. Or shorter, if we understand a mythology in its functional terms, its function is to explain the world and its meaning, and out of this, the position and meaning of man inside it (cf. Campbell, 1996, pp. 15-17). The "rightness" of human activities, e.g. in the daily conduct of a management context, is derived out of this.

To better comprehend the phenomenon, a few voices about it: A mythos, says Roland Barthes, is not just any saying but a message, an entire system of communication; it is no object, no term, no idea but a way of meaning, a form (Barthes, 2012, p. 251). The mythos, states Eliade in his investigation about the mythic, is a very complex cultural reality that can be interpreted from many differing perspectives assisting, and supplementing each other. For him, the most encompassing and least imperfect definition of a mythos is that "[...] the mythos narrates a holy tale $[\ldots]$ In other words: the mythos narrates in which ways $[\ldots]$ a reality came to existence-be it total reality, the cosmos, or only a part of it [...]"(Eliade,1988, p. 15). Holy has not to be misunderstood; taking the nature of a mythos as a narrative, a myth is not just a story, or a legend-it is more than that, it is a tale. A tale not doubted since it provides the very fundament of interpreting, and acting in the world. Here, 'holy' means a sacrosanct, not questioned narration (no matter its respective appearance) about the "world as it is"-at least about the relevant world as it is, that domain (or domains) of an entirety-a 'reality' in its total-that we believe to be of importance for us. Regarding the mythos, so Eliade, there is a separation in 'false' and 'true' stories (the latter being tales then); legends, fables, fairy tales are 'false' stories not because they are overtly wrong or just fantasized but because they are no myths. Because they do not, opposed to myths or 'true' tales, directly affect the human existence as such, in its foundations. Since myths, by being true tales, narrate what directly affects 
and constitutes the human being ab origine. "And everything what concerns his existence and his way of being in the cosmos is directly affecting him" (Eliade, 1988, pp. 18-21). A myth is no assertion for 'explaining' a (whichever constituted) world but true; it does not answer certain questions but makes unquestionable (Blumenberg, 1996, p. 142).

A myth, so another investigator, comes equal to a certainty of faith. In this sense, it is a holy and therefore true tale; it is 'true' because it is 'holy' (and not vice versa), believed in with all security of the undoubted, unquestioned. Myths are ultimate sacred postulates, as he puts it, since they provide the basic "assumptions" upon which all the other assumptions that constitute our world view in question build upon (Rappaport, 1999, p. 21). In a literal sense, a myth is a religious narration, a one we (who believe in it) are re-bounded to; from the Latin religare, being re-bound to something in the sense of certainty, assurance and guidance (cf. Hoffmeister, 1955, p. 525).

In this respect, and with a look at management matters, two aspects of such kind of narrations are of specific importance: Their religious undoubtedness, and their relation to history; a relation which too influences the outer form, the appearance of myths. Being an undoubtedness that embodies a known unthought, myths are tautegorical, as Schelling put it, one of the very first researchers of the mythic in systematic, scientific terms. They refer to themselves, in relying upon themselves in a self-referential or "operationally closed" way (Cassirer, in Verene, 1979, p. 235). Otherwise, they would be no myths but just common or 'false' narrations open to critique, i.e. to doubt. Such a tautegorical character also affects their appearance: For the believers of the mythos in question, it is sufficient to know (unthought) its narrative core-you don't have to know the whole tale to know what it is all about. A myth of the free market for instance, consisting in its narrative core in Free Market = Democracy $=$ Freedom can adopt many different forms, as a complete narration-of a neoliberal economic theory, of an elaborated guideline how to proceed in restructuring entire industries (in the author's case), of the respective narratives to pacify the ones subdued under the mythos' rule (why your industry and hence, your enterprise has to be transformed, with dozens of rationalizations); but irrespective of these concretized outcomes as a detailed narration put into practical operation, its narrative core, consisting of the above mythological equation, remains the same Unthought Known. Myths, so Blumenberg, another prominent researcher of the mythic, "are tales with a high constancy of their narrative core combined with marginal capability for variation". Both features make myths suited for tradition, he says; their durability offers the possibility to articulate them in many different ways of ritual and imagery, and their respective versions offer the chance to try them anew over and over, in ever new forms (Blumenberg, 1996, p. 40).

\subsection{Myths and the Practice of Morals}

The latter aspect is of particular importance when related to management matters. Since a certain mythic preconception about a relevant 'world as it is' which again is rooted in other culturally based and historically deep-layered mythic images-for instance, the Christian imagery that as such, the world is hostile and (therefore) that man has to dominate it-now can become reconfirmed. In the case looked at here: because the world is hostile and because it has to be dominated, i. e. to become subdued under man's rule, mind has to rule over matter; and it must be possible, as an ontological necessity, that mindful artifacts (of management, and to be managed) have to be posed upon a world "as it was" in its original, so to speak natural state. That following the mythos of a second creation, it is a necessity to create the relevant world anew-as a mindful and functionalized artifact serving human purposes. To summarize the relevant old, archetypal imagery of a management mythology or 'system' of myths the author experienced, in his management praxis.

These old images make up a great part of what had been called cultural memory, inherited symbolic figures for which it is not necessary to keep the past as such (what really happened) but to have the quality of an evident unthought known (Assmann, 1997, p. 52). As a consistent system of myths, these old images make up a mythology by becoming affiliated with other myths associated, or "clustered" around them, myths of newer origin; e.g. the one of the free market. In its entirety as a corpus, a mythology then consists of 'old' myths, providing the basal imagery of a 'world as it is', and new ones settling upon them. And this entire corpus of central beliefs (if one wants to avoid the term 'myth') not only justifies itself in a self-referential way, but moreover, offers the chance of becoming realized in ever new forms, as Blumenberg said it. As long as such a corpus is believed in, of course, and thereby enabled to act, to "inform" those who believe in it; and who ground both their activities and interpretations of an outside 'relevant' world on it.

A mythos must be believed in to be active, it must be lived. In the above case of a management mythology, we can see also the practical impact: The myths cited contain a moral obligation, a need to act, to realize them in practical terms. This relates to the nature of mythic truth, namely to embody a 'holy' tale and through that, a 
certainty of faith. Mythic truth is "not simply veracity, a possible property of expressions, but verity, a necessary property of what is" (Rappaport, 1999, p. 294). And of course, it is man's obligation to realize what is, to sustain and to nourish it through constant effort. Because otherwise, the world (and in particular its 'relevant' domains) would fall back into chaos, into a kind of unorderly state not suited to man. Myth creates meaning by naming the things-that is: By arranging them in a certain order and through that very act, to give them meaning-and it lets man live, in that it is breaking down the overwhelming force of a name-less reality (Blumenberg, 1996, pp. 32-38).

The more since these names and meanings are organized as dichotomies, by their nature, and so are the narratives they constitute: Myth is a drama, states Cassirer, a narration working with antagonistic forces. But it does not stay as a mere narrative in the sense of mere interpretation that passively "looks at" the world by just interpreting it. One would misjudge the true character of a mythos, he says, if one would interpret it as a mere narrative or representation. That a myth is, too, but moreover, it is a narrative that entails an obligation to do something, to act. "Even in its primitive, in its "naive" and unsophisticated form, myth does not serve as mere theoretical purpose. It does not give us a mere "representation" of the world. Its principal role is to arouse emotions and to prompt man to certain actions" (Cassirer, in Verene, 1979, p. 238). A myth becomes the paradigmatic model for all the relevant human activities due to its nature, to be a holy and therefore true tale; since each of such tales always has to do with realities (Eliade, 1988, p. 16). In its original meaning, a paradeigma denoted an inner image which serves as both a measure and a blueprint of guiding character (Hoffmeister, 1955, p. 450); it is the measure and blueprint for relevant activities in, and for interpretations of worldly belongings. In these regards, paradeigma was closely related, almost synonymous, to eidos and morphe, both of them denoting Gestalt or idea (which too were used synonymously; cf. Knobloch, 1981, p. 24). With reference to the mythic, summarized this means that I have an inner image in a patterned way (Gestalt) that acts (a), as a knowing unthought in which I do believe as verity and which provides meaning and thus, orientation; which (b), serves as a guideline, paradigm that (c),is prompting me to action.

Inferred from the author's practical experience at least, one has to understand all this-in its holistic, interdependent qualities-to gain an understanding of the mythic and its practical, reality-shaping force. For this, it is useful to look at etymology, too-what some words, and first and foremost, the ideas they want to express originally meant. Such an approach proves to be helpful in revealing the entire scope of these ideas, including, to express it in a postmodern diction, the meta-level of meaning(s) they actually contain. All such notions, so one of their investigators, are polysemantic and hence, ambivalent, they offer no clear-cut, unidirectional meaning. They can be interpreted as containers, he says, which are changing over time but which do not replace their old meanings by new ones. Instead, they experience a "semantic accumulation" and will become, historically, "specific expressions of a culture of the complex". There is an overlap of meanings whereby the newer ones mostly refer to the older (Vercelloni, 1994, p. 4).

This also applies to myths being "paradigmatic" models, and to notions as management, or praxis. And management, besides being culturally grounded and expressing some narratives about a 'world as it is', is praxis, in the first instance. Originally, praxis meant not just doing something (in the sense of performing) but a state of mind, consisting of an ethos of how to perform at all. Opposed to our recent understanding of the practical which is grounded in modernity, praxis was a kind of doing that was politically and ethically motivated, opposed to the mere doing-of-something, the poiesis (from which our word 'poetry' stems). What we understand as praxis today was mere poiesis, and the praxis, in being a more encompassing "doing", denoted the specific state of mind in which, and the mindset through which I am performing something (Mittelstraß, 1981, p. 38f). Understood in such a way, praxis implied a moral dimension out of which, and through which things became done; and understood in this way, it indeed is crucial for management, too in its recent, and quite 'practical' comprehension. Originally, moral not primarily included normative statements (the modern understanding of morality, cf. Berlin, 1998, pp. 298-302) but just meant the mental manner in which things get done, too justified by tradition, i.e. by the cultural memory mentioned earlier (Hoffmeister, 1955, p. 412) in managerial terms: Moral just denotes "the way we do the things around here", a way specific for our peculiar "management culture" practiced in the institution $\mathrm{x}$, or $\mathrm{y}$.

Seen in this way, management-because it is practical in the sense described above-is a moral issue. And since myths, when becoming practically applied, i.e. realized, are expressing themselves through a certain moral of application, this connection is crucial for the relationships that exist between management, and myths. 


\section{Management and Myths}

\subsection{More about Management}

Management itself can be seen as the epitome of an applied morality, and from such a background, its cultural pre-understandings are of particular interest. Management, having its roots in the Latin manu- or manus agere, to keep the strings in one's hands, later on (presumably in the Renaissance) associated with maneggiare, to keep horses at bay, is as old as organized mankind itself. So is our cultural memory, and imagery about management. And in these regards, deeply associated with other mythic notions related to McLuhan's man the cultural animal: It is a technique, and it applies to civilization. And it relates to progress, to leave a purely 'natural' state in becoming more and more civilized, i.e. managed.

Together with all accompanying 'dramatic' ingredients, reflected in the respective mythic images. Tubalkain, the master of metallurgy and founder of the first city (according to the biblical mythos), was a descendant of Kain; according to cultural anthropology, the city, symbol for civilization, and first of all, for a centrally managed civilization, was seen in all its ambivalence right from its start (Leroi-Gourhan, 1984, p. 226). An ambivalence which is not reflected, neither apparent, in its formal definition: according to a systemic view upon management, that is, according to a view that looks at the 'relevant' entities of a 'world as it is' as technical entities to be conceived as functional systems, management equals the conduct of "purpose-driven social systems", that is, of "social institutions in which people work together to fulfill certain purposes" (Ulrich/Probst, 1990, p. 232). According to recent vistas from cultural anthropology, the progress of man as an organized being was closely related to an economy-driven functionalization of human life, resulting in the respective historical levels of managed optimization (e.g., in Gowdy, 2004, p. 253ff) and in centralization plus suppression, the Tubalkain-side of that story. This is a narrative about management that got repeated in ever new forms, and variations-as Blumenberg said about the mythos. As economic subsystem of society becoming de facto independent from the others (Polanyi, Luhmann); as civilization-machine suppressing man from its very beginning (Mumford); as techno-civilization depicted in the imageries of virtual worlds from Fritz Lang to Gotham City to recent dystopian portraits; as embracing capitalist system.

In parallel to that progress-oriented mythical sight fueled by ambivalence, the role of management for cultural development has been relativized-from those concerned with management on a professional base: "[...] if not in its name, management is as old as the necessity to use the coordinated work of several people in order to carry out tasks which exceed the strength of a single individual, then it becomes clear that management, in its many historical variances-from the forms of coordination used in the pre-historic hunt up to the landing of man on the moon-has in fact played a role in the context of socio-cultural evolution. Of course management, in this wide, all-embracing view, has neither determined nor controlled nor guided the process of socio-cultural development [...]" (Malik/Probst, 1984, p. 107). Which is in overt contradiction to the facts, in particular since the sway of a so-called "neo-liberal" or "liberated" capitalism since Reaganomics and Thatcher, facts the author both experienced and tried to install, by triggering real cultural turns in countries of the former Socialist realm (for a general discussion of the influential role of management on matters of a so-called background culture see Haynes (2009). When we listen to other voices, management could attain the status of an all-embracing praxis, even a life form: it became a myth, and a hubris at the same time. Either, its myths have been debunked completely, revealing that all its stories at some level come out to be the same (Stewart, 2010, p. 17) which they are, on a mythological base, and which has to be shown-leaving aside any "cultural turns" that might assigned to them by non-managerial outsiders, and revealing the emperor's nakedness despite his ever new clothing. Or it has been tried to reveal such stories' operation in praxi as mythic constellations (e.g., in Athina, 2011), irrespective of their failures in quite practical, i.e. actual terms of operation. This is interesting. A myth (or a mythology, respectively) has not to prove its veracity on practical grounds, on the base of the facticity of the generated. It is sufficient if it owns verity, and that such a verity is believed in. The failures can be explained then as "collateral damages", as side effects unwillingly generated during the pursuit of the right goals, etc. That means: Myths generate the realities suited to them (also the unwanted ones), but 'real' reality is not able to endanger the myths in question. Nevertheless, reality is used to justify the myth. Because (so the thesis), by including a moral obligation to act, each mythos generates the realities suited to it. In a tautegorical, self-referential circuit, the myth in question generates the realities which are in accordance with it, and these realities in turn justify the myth, "prove" it to be right: Because the world is as it is (generated by the myth), the myth explaining that world is the proper one to explain it.

\subsection{Management and Mythos}

If a myth is summarized, in this context, as "consisting of beliefs and values which serves to provide meaning to 
human action" (Bowles, 1996, p. 2), and if these properties are shaped into a narrative-no matter how rudimentary or elaborated-what is the narrative core of a typically 'modern' management mythos? To achieve a world as function. Not just to manage existing entities of a 'world as it is' in a functional way-this is trivial, because every management has to be functional in some way since it is purpose-oriented-but to mold the (thought of) world of relevance into a system of functionalities, or abbreviated: into a world as function.

The world 'as it is', in its pristine state so to say, has to be transformed; not only here and there, and from time to time (leaving some remainders of it untouched), but in general, and as a whole. In the above sense of an inner eidos, the idea is to achieve a world as ideal artifact in terms of functions. Ideal is to be understood in two dimensions here, in parallel: In the common meaning of being "ideal" in that an end state has to be reached which is optimal as a perfect state, an "absolute model", or at least optimized (the claim of technical processes); and ideal in the meaning of that what is preconceived in the mind, as an idea or eidos (Eaton, 2001, p. 11). The mythological claim of a 'modern', encompassing management then is to create a world of relevance that consists in a systemic of functionalities and thereby, to arrive at a relevant world that consists of a network (or interdependent networks) of functional processes arranged as systems. It is a cybernetic ideal that comes to expression here, arranging dynamics ('lively' forces) into formatted patterns ('systems') of functionalities. In other words, the mythic ideal is to cast life processes into the channels of a preconceived ideal absolute model.

Of course, such an ideal is historically deep-layered, embedded in certain basic pre-conceptions, with each of them acting as an Unthought Known of own kind, about the mythological meanings of world, and of humans. And of course, it can pour into many different, even differing, narrations about a world as it is; even in reconciled, rationalized forms (e.g. Gehmann, 2003, to the differences between traditional and modern myths). Moreover, this will to functionality or expressed in terms of Schopenhauer, the will to achieve a functional world based on will and conception, has not to be apparent, e.g. Baudrillard (2014) on recent consumer society, or even more radical, Byung-Chul (2014).

\section{The Myths of Management}

If management is about organizing, finally, arranging the things into their right order and watch that they keep so, and if myth making is the central process of organizing (Schwartz, 1986) what means management, then? When we look at organizing opposed to its outer appearance (also strongly propagated by management): That it is "only" about arranging some functionality, i.e. to achieve the useful via purposive acts-about which usefulness, and which purposes we speak? And which myths are 'made', and which older ones (these myths 'made' settle upon) are reconfirmed? Moreover, what's about the mythic and actual realities generated out of such acts?

\subsection{Mythical Moves}

To take a case example from the author's praxis: In transforming a former Socialist economy-the wrong one, in terms of Cassirer's myth as a drama-into the right one of a capitalist market driven by freed forces, a complex construct was established, a true world as ideal artifact. It was a construction deliberately designed to be of an ephemeral, transient character, and it did encompass the entire former economy. There was a state ownership fund (SOF), and several private ownership funds (POFs), whereby the aim of these POFs was to secure territorial coverage, them directed in their activities by the SOF. It meant, translated into the terms of the mythological: A former mythology that was the official one in charge but nobody believed in any more-Socialism-had to be killed in favor of the proper mythology to get established, that of a Capitalist Free Market. The wrong belief had to become eradicated, and the right one to become established, via that SOF/POFs-construct aimed to (a) cover the entire territory of that former wrong mythology, through (b), destroying all of that mythologies' structures. Organization is about managed spaces, in physical as well as operative terms. One world as ideal artifact (Socialist Economy) had to be replaced by another one (Capitalist Economy). After this has been achieved, the entire SOF/POFs-construct was not necessary any longer, i.e. had to vanish, too. Its function was to destroy and to reconstruct, before it ceased by itself. And of course, such a destruction plus subsequent transformation in creating the new was not confined to economy, but as one can easily imagine, it essentially was a mental and (therefore) cultural issue, too. A myth is about a new beginning, it explains how the world as it is came into existence and-utmost important-its reasons to be, to exist at all (Rappaport, 1999, p. 233). An old world order, mythological-grounded, had to vanish because it was wrong, and a new one had to take its position. Also in this sense, a mythos relates to history: By pursuing what Karl Mannheim (1929, pp. 129-188) in his famous work about ideology and utopia called utopian consciousness, the old history, the wrong one-here, a one based upon the false tale of Socialism-has to be eradicated in favor of a new, and right one. According to the Babylonian mythos of creation, Marduk creates the world anew, by killing Tiamat and forming the new proper world out of her materials. 
What happened? A new, transient world as ideal artifact was imposed on an old, 'wrong' one, in order to reach another, final one that was concordant with the myth of the free market. It was a tripartite historical operation: First, there was an old world, already created as an ideal artifact, that of a Socialist order; which replaced a formerly existing one, that of a false, bourgeois tale (of capitalist origin). This new order had to be replaced again, because it too was a false tale; by a transient world order (SOF/POFs). And then, a third order had to come, that of the free market in its newest, and finally liberated form-the "absolute model" mentioned above, making the former utopia, literally the non-topos, to a topos, to the system of a final (ideal) space realized in mental, physical and first and foremost organizational terms. History as teleology had to be achieved: the final, 'ideal' end state of history is that where there is no history any longer. Since the free market, following Schumpeter's principle of creative destruction, has no history in the real sense. The principle, supposed to embody a driving force of capitalism, states that the very course of a capitalist history consists in constantly bringing forth the new, at the price of destroying the old (Schumpeter, 1943, p. 83). It means that history as such, as an entity in itself has no value-since it is old, outdated: The old technology is less efficient than the new one, yesterday's products less valuable than the ones now, and so on. At the same time, the myth of the free market presupposes an eternal present since it is the (believed) end state of history: there is a history of people, institutions and subsequent creative destructions, of course, but no real one in the sense that something radically new is happening: something other than the free market. And as long as a free market exists, in its real terms, the mythos underlying it is justified. Because it really explains, being the central element of an aligned mythology, the world 'as it is'-now, under the aegis of a free market. Myths, as the respective ends of history, become self-referential: Tautegorical, as Schelling said it.

Interestingly, exemplified by the case study, there was another mythology claiming the very same, to end all of the 'false' history that went on so far by a new kind of world order, a Socialist one. Here too, a world as ideal artifact had to be created, and too it settled upon two other myths decisive for modernity: That individual human beings had to be liberated, and that it is possible to create the world anew, in a process of a second creation; which is an 'old' myth at the same time, due to its Christian origins (to its most recent version as cyberspace-variant, see Eerikainen, 2000, 140f). What came up in its capitalist version as a creatio continua, following Schumpeter's principle a continuous creation or more precisely, a constantly ongoing re-creation of the world (Glacken, 1997, p. 67), was in its socialist version a definitive end, the state of Communism. As in our case of SOF and POFs, to be achieved via a transient state, a so-called Socialism. In the course of this transformation, man will become liberated; in the capitalist version, he is liberated all the time, mainly as consumer having the world 'as it is' at his disposal, as application for gaining resources, products, other benefits (travels to exotic countries, and the like) to constantly liberate himself, in that eternal present mentioned.

\subsection{Management Procedures}

These two main narratives of modernity with regard to the liberation of man, each of them aimed to achieve a true cultural turn (in ending a former history), have one myth in common, a myth related to the one of a second creation: that it has to be, and indeed is possible, to create a functional world. Which, in the first instance, is a rational world, and in addition, a cultural trait deeply embodied in what is called the Occident, since Greek days. "Rationality is one of the leading concepts by means of which we formulate our self-image and understanding of the world", and became a key notion in 20th century organization theory (Schipper, 1996, p. 267). If management, and in particular the occidental cultural model of management, is understood as a specific kind of rational order, namely a one relying upon formats-broadly defined as normed modules/processes which own algorithmic qualities-then producing formats was the ideal for that kind of management. An algorithm is a formal procedure from which it is expected that it will lead to the ever same results once it started. It is characterized by (a), inherent neutrality: The results achieved depend on the logical structure of the process applied (example: assembly line), not on its materials used (example: material inputs, workers); by (b), simplicity: each step in such an algorithmic procedure has to be designed as simple as possible (which became the ideal of a 'scientific' management); and (c), guaranteed results if installed properly, and if no mistakes are made during the processes' run (Dennett, 1996, p. 30). Algorithmic rationality was the dominant theme for Western thought over long periods of time, and it was an "ideal of rationality which implied rigorous norms and criteria for claims about true, propositional, knowledge". Of ultimate importance in these regards were two questions: Are the propositions self-evident? And if not, "can they be deduced according to strict logical rules, which are self-evident or from other propositions which are self-evident?" (Schipper, 1996, p. 268). Here, we see the door wide open for mythic preconditions because by their nature as it has been outlined in the foregoing, they are eo ipso self-evident. If evidence denotes an issue that is immediately clear, either from sensual perception or from mental insight (Hoffmeister, 1955, p. 223), then topics belonging to the domain of an Unthought Known 
claim such an evidence, first of all. And self-evident (inter alias) are such issues or notions which own an axiomatic character. Since Aristotle and Euclid, an axioma is a principle or assumption the truth of which is immediately evident, which needs no proof and moreover, which cannot be verified or falsified at all; and which serves as the base for further assumptions (Hoffmeister, 1955, p. 101). In this sense, myths-as embodying a specific "class" of an Unthought Known-are axiomatic, that is, self-evident, and basic for further assumptions/prepositions about a real/ideas/a world 'as it is'.

And they account for what has been called judgemental rationality, the capability to judge a situation according to its relevance for other parameters-e.g., is this procedure goal-oriented, may it lead to unbearable collateral damages-for other general criteria of relevance (Schippers, 1996, p. 269). And, according to the author's empirical evidence, first and foremost for criteria of a managerial praxis in the above original meaning: Do the procedures going on fit into our general understanding of who we are? Are they compatible with our identity, with what we believe does constitute us, and our organization? And since our identity derives from its mythological substrate, the final question is: Are the procedures/situations/proposals made compatible with our mythology "in use", i.e. in line with our central beliefs? For instance, to refer to the above case example, nobody of the participants would have had the idea not to install free market-conditions, or to do so less than $100 \%$. That is, to do it in a way that would have allowed for a mixture between the "old" world, and the new one to be installed-in a mythological translation: To let alive what has been before, at least in parts. Nobody had such ideas; the result would have been immediate dismissal. Not because of such ideas as such, but because a codex would have been violated, a managerial praxis and its constituting mythic substrate. You would have been a traitor in proposing such ideas. Or to formulate it from a slightly different perspective: You will have to fit into the leading narrative, you have to remain one of its parts; otherwise you are dead, out of the story. As Cassirer said it, myth is dramatic; there exist only clear-cut dichotomies and antagonistic forces, the good vs. the evil. And Socialism was evil because it relied upon an idea of man as a communal animal, and not as an individual that is free to do what it wants, no matter if enterprise (free-acting individual units, too) or single person. The meaning of life is to act alone, and to do so in competition, a meta-narrative to come to. Anybody who would have doubted such axiomatic truths would have been dismissed, as said. Or: You succeed in establishing a counter-narrative, a new mythos providing a new meaning. But in this case, you need followers, people ready to believe in a new meaning, and hence actively participating in molding a new verity, altogether with its praxis.

For a mythic will to create worlds as ideal artifacts of functionality-to liberate man by setting the "proper" conditions properly managed, that is, in a function-oriented manner-it is not too hard to imagine what happens if an ideal of algorithmic rationality is combined with a "judgemental" rationality that poses an emphasis on individualism, competition and the world as an essentially hostile place; the Christian heritage, transformed into inner-worldly belongings, the more since work organizations overtook the role of the traditional Christian Church (Bowles, 1989). It is a world where the meaning of life-an issue every mythos explains, since it explains the basic features of a conditio humana (Campbell, 1996, p. 16f), of us living in this world (as it is, of course) is to act alone in freedom \& competition, and finally to survive.

\subsection{Management and Meta-Narratives}

We see in this example how single myths form into a consistent body, a mythology. Comparable to a painting, we see some figures in the foreground-the managerial myths in question-grouped together and posed against a cultural background consisting of diverse mythic narrations of a more general nature, that what Assmann called cultural memory (cf. above). Or shorter, expressed in functional terms, that ideal of 'modern' organizations and management: If myths are narratives, it needs some meta-narratives (being myths again) in which they are embedded in. And, to stay in this metaphor of the painting, we have to understand the background in order to understand the foreground at all. Through knowing this background (unthought, as a specific memory), history by itself becomes a mythos. And by becoming so, it will not be unreal but on the contrary, will become real at all, as a normative and forming force of perpetual character (Assmann, 1997, p. 52). Through that, history will attain a symbolic value-as are the attempts to at all erect organizations as ideal artifacts, and to endorse them with proper management; to achieve both the mythological correct organization, and management. To cite Cassirer, In being a symbolic animal, such kind of organization-of course, historically changing since depending on the myths and concomitant values being in charge in the respective society-is a symbolic form of prime importance for man the cultural animal. "He has no separate individual being-he lives in the great forms of social life-in the world of language, of religion, of art, of political institutions. He cannot live his own life without constantly expressing it in these forms. He creates verbal symbols, religious symbols, mythical and artistic images-and it is only by the totality, by the system of these symbols and images, he can maintain his social life-that he is able to communicate with other human beings and make himself understood by them"(Cassirer, in Verene, 1979, p. 
137). And, to conclude, it needs to re-think management in its recent forms-them only a transient historical expression of Cassirer's symbolic forms-from this background.

Seen from such a perspective, to erect a world as ideal artifact adopting the shape of a functional organization that is 'ideal' in both meanings of the word is rather difficult if the world 'as it is' has no meaning in itself. And as a result, is populated by individuals (persons, enterprises, other institutions) which compete against each other-but which are free, the major issue. And even if there is no historical meaning any more since every single one of these free-acting units is subjected under the aegis, the nomos of an encompassing competition, free to use the world as it is for its own purposes and belongings (in itself, a meta-narrative of own rank) and as a result, lives in an eternal present subjected under Schumpeter's principle, there is some background left. Some general conception of history "as such", present in the minds of the single actors as an unthought known, despite the reign of an eternal present governed by competitive moves and their assigned uses of the world as an application-pool (reflected in the recent predominant conditio humana of being a user). If cultures and societies can be comprehended as a reality that is symbolically constructed, finally (Böhme, 2001, p. 150), then the trope of the ideal artifact gains an additional momentum, in particular in a competitive, eo ipso meaningless world.

One of the major achievements of Darwin, we read in a recent textbook about the human condition, was to give up major goals (of history) in favor of a selection that lacks any plan and acts opportunistic, thereby not anticipating the future. And this is natural, the course of events characterizing a world as it is. Natural selection, we read there, does not bring about a perfect organization but only "relatively optimal" structures, functions, and behavioral patterns. Since evolution (i.e., history) is a self-organizing process that self-referentially regulates itself and generates its own rules (Wuketits, 2010, p. 29). Applied to organizations and management as culturally anchored symbolic forms, we read in another textbook: Organizations today live in a world of hyper-competition where old boundaries and assumptions are no longer valid, due to globalization and the emergence of new types of customers (that specific, individualized kind of world-user). "Hypercompetition places new demands on how firms must organize in order to survive [...]. A mode of organizing is required that encourages initiative and innovation aimed at retaining a strategic advantage over competitors. Simply adapting in response to events may not be enough for a firm to survive under conditions of hypercompetition (Child, 2012, p. 40). This has been not written in the days of Herbert Spencer, but quite recently. What it means, in a mythological translation? To put it in a broader context, first of all for history itself such vistas reflect the common mythic imagery about modern times (our one, a so-called post-modern era included), an imagery that can be seen as 'traditional', meanwhile: Modernity equals acceleration, fragmentation (that is, individualization) and "flexibility", that mythic demand standing in the first line of survival needs, not only for firms. From Paul Virilio's dromocratic societies to Baudrillard's hyper-reality to the diverse heterotopias of consumption and illusion of Foucault, making up the majority of today's real spaces (Shane, 2013, p. 75), next to other non-places (Augé, 1995) the real spaces to live in, a real cultural turn since the onset of classical modernity, everything seems to accelerate, to individualize and to become fluid. It is an overall situation that poses an emphasis on the "relatively optimal", and its concomitant constant threat through Schumpeter's principle. If we follow such a neo-mythology to its logical end, it means (and myths provide meaning, we recall) that the meaning of history-and hence, of a world 'as it is'-consists in maximizing the relative fitness of the respective individual unit, e.g., a firm.

As regards the latter, in embodying an individual unit that through its activities, molded modernity (also in cultural terms) as encompassing as no other one, it is severely hampered in its survival efforts-not primarily due to hypercompetition, but first and foremost due to itself, its very nature: namely to be a firm, a "purpose-oriented sociotechnical system" (we recall the nature of management) that has to obey to a strict functionality: To ensure rentability as the very base of its survival. As Max Weber stated already, at the end of a Fin de Siecle, the operation of a firm is not identical with the search for profit. The reach for profits has been not confined to a capitalist era, this "irrational" motive was present in all times, and in all kinds of individuals. This is not the point as regards the specific individual of the capitalist enterprise, the firm. Since capitalism is almost identical with a rational tempering of that irrational motive, cast into the functionality of strict rational forms. Profit is needed, of course, but in a peculiar way: It has to be profit in series, on a constant base, as rentability. The latter is a necessity for an enterprise of the capitalist type, since without it the respective firm would be damned to extinction (Weber, 2006, p. 13). Far away from any mythology, there apparently exist actual systemic properties, also as historical constants, which now have to get mythically explained; on the one hand. And on the other, it were certain myths or central beliefs that at all led to the emergence of such "real historical facts". For instance the one to liberate individuals, and combined with new technological possibilities overcoming the "wooden societies" of a pre-industrialist era which were, in being "wooden" and lacking the possibility of industrial 
production on large scale, eo ipso confined in their possibilities of growth (Radkau, 1998, p. 389), to liberate individuals capitalistically.

\subsection{The Myths of Management}

In these ways, actual conditions historically present and ideas intermingle, and on the top of that, interfere with "old" images of mythic origin and their descendants. And in their total generate what Max Weber already called a capitalist cosmos: An "immense cosmos of a capitalist economic order" in which the single individual is embedded in from birth onwards, and which is given as a "factual frame not to change inside the terms of which the individual person has to live" (Weber, 2006, p. 39). Altogether with its most prominent and influencing individualities, the single enterprises following the strict rules he described in the foregoing, just to survive-that means, translated: Just to exist, far away from any additional meaning.

How to achieve survival, inside such a scenario where the only meaning seems to be competition, and surviving? With a myth of the ideal order, a one that is based on the free-acting individual unit of this new cosmos: The enterprise. This has not to be misunderstood, especially not since the downfall of the other kind of ideal order trying to achieve a bonum commune for all, Socialism; and especially not in conditions of hypercompetition. Now, the bonum commune is achieved by each of the individuals alone, because according to the prevalent neoliberal mythology this will lead, with the help of some helpful hand of a self-organizing systemic, to a bonum commune for all. Because only free market equals freedom equals democracy (we realize the tautegorical that according to Schelling, characterizes the mythic). The myth of such an ideal order is not attached to fixed structures-the acting individual (the firm) has to stay flexible in conditions of hyper-competition-it is a mental model, an idea; expressed in a myth of management. Which is a myth emphasizing the following features: "Firstly, a belief in competition both in the internal and external management of organisations; secondly, an economic imperative which dictates the primacy of growth of markets and profits over considerations of community, individuals and ecology; and, thirdly the pursuit of 'functional rationality', whereby organizational activities and work processes are rationalized and broken into their constituent parts so they can be completely controlled" (Bowles, 1996, p. 9). This mythos, coming close to a religious fundamentalism (Bowles: ibid.), generated the realities suited to it, in that it "monopolised the goals and informed the understandings and mindset" of our late 20th century and recent societies. It itself rests upon two other myths, the one of a Social Darwinism and a one of functional rationality (ibid.), concludes that investigator of the mythic in its recent form. Social Darwinism, already indicated above, led to a self-fulfilling evidence, as in case of every mythos: the mythos of Social Darwinism, claims Bowles, led not only to an increased actual competitiveness between individuals (of enterprises and persons alike) during the course of the $20^{\text {th }}$ century, raising the belief that competitiveness inevitably belongs to a conditio humana, it moreover established the belief that competitive capitalism is the final truth of history (Bowles, 1996, p. 11). That means, if history is conceived as embodiment of progress that the recent stage of history-that of neoliberal capitalist conditions-cannot be surpassed by an alternative model. And related, it means that the ultimate liberation of humans is identical with maximizing self-interest. To recur to the case example given earlier, one of our very prerequisites of success in preparing the grounds for a free market-myth was the readiness of the ones to be colonized by it: They all believed that indeed, free market equals individual liberation. Which is true, of course, since a mythos is not identical with a lie because it is no false tale-albeit it came true not in the way these people thought of.

Moreover, as the functional rationality to come to, it can justify itself the longer it succeeded to establish itself, in terms of actual historical existence (or duration of 'survival', to use Darwinian terms). Because in generating a world suited to it, the mythos proves to be right-isn't the world in the way that it has predicted it to be? In concrete terms of actual history and actual organization, an effect comes into play which Max Weber called rationality of rightness: The fact that seemingly purpose-rational phenomena had been created at the beginning of their life by motives which have nothing to do with rationality, but which had, in generating general conditions of actual life, adopted the appearance of being "technical-rational" and in this respect, have survived as "adapted"; and not seldom, gained universal spread out (Weber, 1992, p. 105). The evidence of the mythic is that it explains the world, and this explanation is proven by the fact that the world is 'as it is' in the manner the mythos explains it to be. But it is even more than this-the effect that in a world of dinosaurs, it seems that dinosaurs will live forever-it is the momentum gained. Once a certain life system and its mythic conditions "survived", they tend to establish themselves more and more, and if connected with a certain mindset of making the world to an object, here: of functional rationality, this tendency will accelerate.

The other constitutive myth for the managerial one, that of a functional rationality as Bowles termed it, is even more interesting in these regards. Functional rationality is not identical with rationality as such, and also not identical with mere technical rationality. As Weber argues-already again at the beginnings of a recent capitalism 
to unfold-the capitalist enterprise is interested in a peculiar kind of rationality, a one allowing for the maintenance ('survival') or even the maximization of rentability. Its aim consists in "the creation of a principal rational being", of artifacts which principally allow for rational creation, knowledge, and control, that is, which become calculable in their behavior (Weber, 1992, p. 150). At this point, the algorithmic rationality mentioned above comes into play: The most rational since most calculable entities are those which obey to an algorithmic procedure; which are formats. And which are the result of, and obey to, processes of formatting (Gehmann, 2012).

But although it enhances it, this is not the major issue to be considered here; it is the mythology behind it, the "meta-narrative" told through, and by these technical properties. In this respect, it is even not primarily about a myth of functional rationality, as Bowles claims it; but about another meta-narrative, that to make an artificial world by its own, and out of man's own powers, in prolongation of a Christian myth of a second creation. And assigned to it, the myth of liberating the individual through this very act, in a Promethean gesture, to create world anew with the help of technique (the original core of the promise of Prometheus, and narrative core of the myth aligned), in particular with techniques of management (Gehmann, 2004). The latter first pouring into what Bowles (1996) calls a myth of technical rationality, epitomized in the attempts to install a "scientific" management in the mode of Taylor and Fayol, and in the wake of it, to follow the ideal of the organization as a machine (Giedion, 1994, p. 120). There was the search for some mechanismus cosmicus, following the tradition to create a world as a machina mundi (Mittelstraß, 1981, pp. 53-56), in order to fulfill the Promethean promise.

\section{Ideal Spaces}

And it was found, finally, irrespective of all former fruitless trials to create constant orders of management and control, which cannot survive in the face of hypercompetition and Schumpeter's principle. It was the value chain, a perfect mechanismus cosmicus since not dependent on any given, concrete world (cf. Gehmann, 2012, p. 85). In that sense it is a space of pure abstraction, coming close to the ideal of (an almost perfect) calculability and functional rationality. If capitalism is per se a utopian venture in generating systems that operate independent from concrete human beings or other material substrata-they need them only as "inputs" for calculable and essentially algorithmic operations-than this kind of space was not just the fulfillment of a mythical promise to overcome the given, it was its perfection. The value chain is a space, but a one of complete abstraction. And it transforms, in prolongation of the idea of a creatio continua, the given (materials, people, other "inputs") into some other forms of being ("outputs"), a kind of inverted teleology resting in itself, and aimed to constantly produce rentability; at the end of the day, to cite that managerial saying. All materials of an originally given world can be transformed if they become the object of capitalist calculus, and only though this transformation, value is added to them-in making them to something different than they have been before. It means, for a mythological translation, that they had no real value before, that they have to be re-molded into something different in order to obtain value at all. That is, they have to be privatized in a literal sense (from the Latin words for separating, or depriving), namely from their original being, their pristine individuality so to speak, and to be transformed into something other, namely into something functionalized that has obey to some (managed) functions. It too is an individuality, but a different one, a virtually abstracted one. This embodies not only a consequent destruction of original entities, but a utopian operation, finally. Since the 'original' entities are stripped off their original, so to say genuine being by making them to something other. In its original meaning, abstraction denoted not only the stripping off from something concretely given (the Latin ab-strahere), but also the conception for something new, the "mind's active grasp of form" (Summers, 2003, p. 26).

The value chain is no utopian space in the strict sense, but a-topian since it does not need concrete spatiality (despite it embodies a space), opposed to traditional utopias which at least assume some future spaces, concrete spatialities to be reached someday, and/or to be built accordingly (cf. Vidler, 2011, p. 9). At the same time, the value chain-as a closed, abstract cosmos of functionality independent from concrete space, or place-can be seen as the epitome of managerial mythology; because it is independent from all this. And because it transforms-everything. What historically started with the idea of an abstract space, a Cartesian spatium opposed to the concrete place, the Aristotelian topos (Böhme, 2013, p. 15), became further elaborated with the idea of a capitalist enterprise, a perfected functional organization as the ideal space for, and of management. An entity about which Werner Sombart said that it is "pure mind", abstraction from any concretely given in the most consequent, i.e. most functional way (Sombart, 1927, pp. 895-900), thereby reaching that myth of functionality Bowles spoke of. What had been undertaken in case of traditional utopias with a "construction of the void", in an attempt to long for a perfect symmetry between transparency and utopia (Vidler, 2011, p. 130), it succeeded here, in that a-topian space. At the same time, despite atopian, it was a space the application of which could transform 
real worlds, and to do so in an encompassing manner, see Weber's comment about a capitalist cosmos as a real life world, and not just an imagination: Mythology stays alive.

\section{References}

Assmann, J. (1997). Das kulturelle Gedächtnis. Schrift, Erinnerung und politische Identität in frühen Hochkulturen. Munich: C. H. Beck.

Athina, A. (2011). Financial Crisis: The myth of free market ideology and current regulatory reforms. International Journal of Management Concepts and Philosophy, 5(3), 218-230. http://dx.doi.org/10.1504/IJMCP.2011.043755

Augé, M. (1995). Non-Places. Introduction to an Anthropology of Supermodernity. London, Verso.

Bachmann-Medick, D. (2009). Cultural Turns: Neuorientierungen in den Kulturwissenschaften. Reinbek bei Hamburg, Rowohlt.

Baecker, D. (1999). Organisation als System. Frankfurt/Main, Suhrkamp.

Barthes, R. (2012). Mythen des Alltags. Berlin, Suhrkamp.

Baudrillard, J. (2014). Die Konsumgesellschaft. Ihre Mythen, ihre Strukturen. Wiesbaden, Springer.

Berlin, I. (1998). Wirklichkeitssinn. Ideengeschichtliche Untersuchungen. Berlin, Berlin Verlag.

Blumenberg, H. (1996). Arbeit am Mythos. Frankfurt/Main, Suhrkamp.

Böhme, G. (2013). Architektur und Atmosphäre. Munich, Wilhelm Fink.

Böhme, G. (2001). Aisthetik. Vorlesungen über Ästhetik als allgemeine Wahrnehmungslehre. Munich, Wilhelm Fink.

Bollas, C. (1987). The Shadow of the Object-Psychoanalysis of the Unthought Known. London, Free Association Books.

Bowles, M. L. (1997). The Myth of Management: Direction and Failure in Contemporary Organisations. Human Relations, 50(7), 779-803. http://dx.doi.org/10.1177/001872679705000702

Bowles, M. L. (1989). Myth, Meaning, and Work Organisation. Organisation Studies 10(3), 405-421. http://dx.doi.org/10.1177/017084068901000306

Byung-Chul, H. (2014). Psychopolitik. Neoliberalismus und die neuen Machttechniken. Frankfurt/Main, Fischer.

Campbell, J. (1996). Mythologie des Westens. Munich, dtv.

Child, J. (2012). Organization: Contemporary Principles and Practice. Malden, etc. Wiley.

Dennett, D. C. (1996). Darwin's Dangerous Idea: Evolution and the meanings of life. ZEIT, 8.

Eaton, R. (2001). Die ideale Stadt. Von der Antike bis zur Gegenwart. Berlin: Nicolaische Verlagsbuchhandlung.

Eerikainen, H. (2000). Cyberspace-Cyborg-Cybersex: On the Topos of Disembodiment in the Cyber Discourse. In Flessner, B. (Ed.), Nach dem Menschen. Der Mythos einer zweiten Schöpfung und das Entstehen einer posthumanen Kultur. Freiburg, Rombach.

Eliade, M. (1988). Mythos und Wirklichkeit. Frankfurt/Main, Insel.

Gehmann, U. (2012a). Formats. New Frontiers in Spatial Concepts, 4, 13-33. Retrieved from http://ejournal.uvka.de/spatialconcepts/archives/1494

Gehmann, U. (2012b). Der kapitalistische Kosmos als mythisches Bestreben. Die Virtualität des Realen. In U. Gehmann, (Ed.), Virtuelle und ideale Welten. Karlsruhe, KIT Publishing.

Gehmann, U. (2004). Prometheus Unleashed: The Quest for Knowledge and the Promise of Salvation Through Technique. In Y. Gabriel, (Ed.), Myths, Stories, And Organizations. Oxford, Oxford Univ.

Gehmann, U. (2003). Modern Myths. Culture and Organization, 9(2), 105-119. http://dx.doi.org/10.1080/14759550302805

Giedion, S. (1994). Die Herrschaft der Mechanisierung. Ein Beitrag zur anonymen Geschichte. Hamburg, Europäische Verlagsanstalt.

Glacken, C. J. (1997). Traces on the Rhodian Shore. Nature and Culture in Western Thought from Ancient Times to the End of the Eighteenth Century. Berkeley etc. Univ. of California Press.

Gowdy, J. M. (2004). Evolution of Economics. In F. M. Wuketits, \& C. Antweiler (Eds.), Handbook of Evolution 
(Vol. 1). The Evolution of Human Societies and Cultures. Weinheim, Wiley VCH.

Haynes, M. (2009). History, markets, hierarchies and institutions. International Journal of Management Concepts and Philosophy, 3(3), 205-224. http://dx.doi.org/10.1504/IJMCP.2009.023335

Hoffmeister, J. (1955). Wörterbuch der philosophischen Begriffe. Hamburg, Meiner.

Knobloch, E. (1981). Das Naturverständnis der Antike. In F. Rapp, (Ed.), Naturverständnis und Naturbeherrschung. Munich, W. Fink.

Leroi-Gourhan, A. (1984). Hand und Wort. Die Evolution von Technik, Sprache und Kunst. Frankfurt/Main, Suhrkamp.

Malik, F., \& Probst, G. J. B. (1984). Evolutionary Management. In H. Ulrich, \& G. J. B. Probst (Eds.), Self-Organization and Management of Social Systems. Insights, Promises, Doubts, and Questions. Berlin etc. Springer. http://dx.doi.org/10.1007/978-3-642-69762-3_8

Mannheim, K. (1929). Ideologie und Utopie. Bonn, Friedrich Cohen.

Mittelstraß, J. (1981). Das Wirken der Natur. Materialien zur Geschichte des Naturbegriffs.

Radkau, J. (1998). Natur und Technik-eine dialektische Beziehung? In Dülmen, R. van (Ed.), Erfindung des Menschen. Schöpfungsträume und Körperbilder 1500-2000. Wien, etc. Böhlau.

Rappaport, R. A. (1999). Ritual and Religion in the Making of Humanity. Cambridge, UK: Cambridge Univ. Press. http://dx.doi.org/10.1017/cbo9780511814686

Schipper, F. (1996). Rationality and the Philosophy of Organization. Organization, 3(2), 267-289. http://dx.doi.org/10.1177/135050849632010

Schumpeter, J. A. (1943). Capitalism, Socialism, and Democracy. London, Allen \& Unwin.

Schwartz, H. (1986). The usefulness of myth and the myth of usefulness: A dilemma for the organizational scientist. Journal of Management, 11(1), 31-42. http://dx.doi.org/10.1177/014920638501100104

Shane, D. G. (2013). Recombinant Urbanism: Conceptual Modeling in Architecture, Urban Design and City Theory. West Sussex, Wiley.

Sombart, W. (1927). Der moderne Kapitalismus. Historisch-systematische Darstellung des gesamteuropäischen Wirtschaftslebens von seinen Anfängen bis zur Gegenwart. Munich/Leipzig: Duncker \& Humblot.

Stewart, M. (2010). The Management Myth: Debunking Modern Business Philosophy. New York: W. W. Norton \& Company, Inc.

Summers, D. (2003). Real Spaces: World Art History and the Rise of Western Modernism. New York: Phaidon Press.

Ulrich, H., \& Probst, G. J. B. (1990). Anleitung zum ganzheitlichen Denken und Handeln. Ein Brevier für Führungskräfte. Bern \& Stuttgart, Paul Haupt.

Vercelloni, V. (1994). Europäische Stadtutopien. Ein historischer Atlas. Munich, Diederichs.

Verene, D. Ph. (1979). Symbol, Myth, and Culture. Essays and Lectures of Ernst Cassirer 1935-1945. New Haven \& London: Yale Univ. Press.

Vidler, A. (2011). The Scenes of the Street and Other Essays. New York, The Monacelli Press.

Weber, M. (2006). Religion und Gesellschaft. Gesammelte Aufsätze zur Religionssoziologie. Frankfurt/Main, Zweitausendeins.

Weber, M. (1992). Soziologie. Universalgeschichtliche Analysen. Politik. Stuttgart, Kröner.

Wuketits, F. M. (2010). Evolution: Treibende Kräfte in Natur und Kultur. In J. Oehler, (Ed.), Der Mensch-Evolution, Natur und Kultur. Beiträge zu unserem heutigen Menschenbild. Heidelberg etc. Springer.

\section{Copyrights}

Copyright for this article is retained by the author(s), with first publication rights granted to the journal.

This is an open-access article distributed under the terms and conditions of the Creative Commons Attribution license (http://creativecommons.org/licenses/by/3.0/). 